\title{
SAGRADO E PROFANO NO DISCURSO DO ESTADO ISLÂMICO: UMA ANÁLISE DOS TEXTOS E IMAGENS DA REVISTA DABIQ
}

GABRIELA CRISTINA DA SILVA FIAM FAAM CENTRO UNIVERSITÁRIO SÃO PAULO, SÃO PAULO, BRASIL GABICRISTINA97@HOTMAIL.COM

SÍLVIO ANTONIO LUIZ ANAZ UNIVERSIDADE DE SÃO PAULO SÃO PAULO, SÃO PAULO, BRASIL SILVIOANAZ@HOTMAIL.COM 
SAGRADO E PROFANO NO DISCURSO DO ESTADO ISLÂMICO: UMA ANÁLISE DOS TEXTOS E IMAGENS DA REVISTA DABIQ

Resumo: Este artigo analisa a revista Dabiq, produzida pelo Estado Islâmico, a partir do estudo dos valores-notícia, da oposição sagrado-profano, das ideias de persuasão e convencimento e das linguagens conotativa e denotativa nas matérias. O método combina elementos da análise do discurso e da análise semiótica. A conclusão mostra que a publicação recorre a características do jornalismo para legitimar um discurso doutrinário.

Palavras-chave: Jornalismo; valores-notícia; Estado Islâmico.

\section{SAGRADO Y PROFANE EN EL DISCURSO DEL ESTADO ISLÁMICO: UNA ANALISIS DE TEXTOS Y IMAGENES EM EL PERIÓDICO DABIQ} Resumen: Este artículo analiza el periódico Dabiq del Estado Islámico a partir del estudio de los valores-notícias, la oposición sagrado-profano, las ideas de persuasión y engreimiento y del lenguage connotativo y denotativo. Emplease como método la analisis del discurso y la semiótica. La conclusion muestra que el periódico recuerre a las características del periodismo para legitimar um discurso doctrinário.

Palabras clave: Periodismo; valores-noticias; Estado Islámico.

\section{SACRED AND PROFANE IN DISCOURSE OF ISIS: AN ANALYSIS OF TEXTS AND IMAGES IN DABIQ MAGAZINE}

Abstract: This paper analyses the magazine Dabiq, produced by Islamic State, from the investigation of the news values, opposition sacred-profane, ideas of persuasion and convincing, and use of connotative and denotative languages. The method combines elements from discourse analysis and semiotics. The conclusion shows that the magazine invokes the characteristics of journalism in order to legitimize a doctrinaire discourse.

Keywords: Journalism, news values, Islamic State.

\section{INTRODUÇÃO}

O Estado Islâmico (EI), organização político-militar extremista, emerge como foco da cobertura jornalística em 2011. Principalmente, por conta dos atentados que promoveu em vários países e das incursões militares no Iraque e na Síria, que resultaram no controle de partes de territórios desses países com o objetivo de reimplantar um Califado no Oriente Médio. A trajetória do El se destaca a partir de 2014, quando o grupo conquista territórios no larque e torna-se o grupo jihadista mais poderoso do mundo. Mas, no fim de 2017, o grupo havia perdido grande parte de seus territórios. 
Denominado em inglês como ISIL (Islamic State of Iraq and the Levant) ou ISIS (Islamic State of Iraq and Syria) e em árabe com o acrônimo Daesh, o El baseia parte de sua ideologia no wahabismo, corrente extremamente conservadora do Islã. O principal objetivo do grupo é criar um Estado que tenha, ao mesmo tempo, um líder religioso e político, um Califa.

Para conseguir apoiadores, o El utiliza mídias como revistas digitais e vídeos produzidos com qualidade profissional, além de atuar nas redes sociais. De acordo com Gambhir (2016, p. 25, tradução nossa):

O El manteve uma presença digital formidável usando uma variedade de plataformas online. Além do Twitter, os apoiadores do EI postaram mídia oficial em sites de compartilhamento de arquivos, como justpaste.it, e por meio de aplicativos de transmissão como Telegram.

Neste artigo, analisamos as estratégias narrativas que o El utiliza na comunicação com seguidores, simpatizantes e potenciais militantes, a partir de um de seus veículos mais importantes: a revista digital Dabiq, uma das publicações produzidas nos escritórios próprios do El. Além da Dabiq, foram editadas também as revistas Rumiyah, Istok, Dar al Islam e Constantinople.

A Dabiq foi lançada em 5 de julho de 2014, com matérias sobre o campo de batalha, relatórios administrativos e comentários religiosos. Divulgada em inglês inicialmente, ela foi depois traduzida para outros idiomas. Seu título é uma referência à cidade localizada ao norte de Aleppo (Síria), que foi parte de uma batalha histórica em 1516, que levou à vitória otomana e consolidação do último Califado. O El conquistou a cidade em agosto de 2014, um mês após a primeira edição da revista ser publicada, mas a perdeu para rebeldes sírios em outubro de 2016. A revista deixou de ser publicada antes desse acontecimento, com sua última edição em 31 de julho de 2016. Ela não tinha uma periodicidade específica e foram publicadas 15 edições com o objetivo de atrair novos adeptos ao Estado Islâmico.

Nesta investigação, analisamos as matérias de capa da primeira e da última edição da revista Dabiq para mostrar como o El usou as estratégias de comunicação verbal e visual ao longo dos dois anos de publicação da revista.

Para tanto, o artigo apresenta, na primeira parte, uma análise sobre o uso dos valores notícia pela revista Dabiq, a partir da teoria sobre noticibilidade (WOLF, 2008), para, a seguir, mostrar como a questão do sagrado e profano destaca-se no discurso veiculado pela revista - para tanto, recorre- 
mos aos fundamentos da análise do discurso (CITELLI, 2004; ABREU, 2011; ORLANDI, 1999) e aos conceitos sobre sagrado e profano (ELIADE, 1992). Por fim, para ajudar a entender como são articulados os textos e imagens da revista que constituem o discurso do sagrado e do profano, recorremos às perspectivas semióticas sobre imagem e texto (BARTHES, 1984, 1990; SANTAELLA, 2001).

\section{A FUNÇÃO DOS VALORES-NOTÍ́CIA NA DABIQ}

A prática jornalística de seleção de notícias e atribuição de importância a elas está relacionada ao conceito de noticiabilidade e valores-notícia. Para Wolf (2008, p. 202), noticiabilidade é:

O conjunto de elementos por meio dos quais o aparato informativo controla e administra a quantidade e o tipo de acontecimentos que servirão de base para a seleção de notícias, podemos definir os valores/notícia (new values) como um componente da noticiabilidade.

Embora para Wolf os valores-notícia sejam classificados separadamente, eles são complementares entre si, e, além disso, são utilizados em todo o processo de produção das notícias. Portanto, estão presentes na seleção, assim como na apresentação dos produtos jornalísticos. Tais valores também são necessários para a seleção rápida das notícias e na criação de um certo consenso entre os jornalistas. Wolf (2008, p. 207) divide os valores-notícia em quatro categorias:

\footnotetext{
Os valores-notícia derivam de admissões implícitas ou de considerações relativas a: $a$. os caracteres substantivos das notícias; o seu conteúdo; $b$. a disponibilidade do material e os critérios relativos ao produto informativo; c. o público; $d$. a concorrência.
}

Na análise da Dabiq, observam-se os critérios que derivam dos caracteres substantivos das notícias e dois dos critérios relativos ao produto (brevidade e novidade). Os critérios dos caracteres substantivos estão relacionados com a importância e o interesse das notícias, porém, esses dois fatores necessitam de maiores especificidades. Quatro variáveis determinam a importância da notícia: o grau e nível hierárquico dos indivíduos envolvidos no acontecimento noticiável, o impacto sobre a nação e sobre o interesse nacional, a quantidade de pessoas que o acontecimento (de fato ou poten- 
cialmente) envolve e a relevância e significatividade do acontecimento em relação aos desenvolvimentos futuros de uma determinada situação (WOLF, 2008, p. 208).

Nos fatores relativos ao produto, destacam-se a brevidade, que se refere a contar a notícia de maneira objetiva, mas com as informações necessárias, e a novidade, que concerne ao fato de que as notícias devem falar sobre eventos que aconteceram próximos ao momento de publicação da notícia.

Para legitimar a Dabiq como veículo jornalístico, o Estado Islâmico recorre a esses valores-notícia, sobretudo na matéria de capa da primeira edição.

O texto O retorno do Califa trata da declaração feita pelo El em 29 de junho de 2014, após a conquista de territórios na Síria e Iraque, na qual anuncia que as novas terras seriam parte de seu Califado e que Amirul-Mu'minin Abu Bakr al-Husayni al-Qurashi al-Baghdadi seria o novo Califa.

No lead - "No primeiro de Ramadã $1435 \mathrm{H}$, a restauração do Califado foi anunciada pelo porta-voz do Estado Islâmico Shaykh Abu Muhammad al'Adnani ash-Shami (hafidhahullah)" (DABIQ, 2014, p. 7, tradução nossa) - o texto traz o valor-notícia do grau e nível hierárquico dos indivíduos envolvidos, pois a informação é sobre o futuro Califa e feita pelo porta-voz oficial do $\mathrm{El}$, que era um dos líderes da organização que mais chamava atenção (FOX NEWS, 2016).

A quantidade de pessoas envolvidas no acontecimento também é um dos principais valores-notícia. No caso, a proclamação do Califado afeta muitas pessoas que vivem em áreas então controladas pelo El. Estima-se que o grupo chegou a ter, sob seu controle, cerca de 12 milhões de pessoas.

Outro valor-notícia na matéria é o relativo ao impacto e interesse do fato. A declaração do Califado é algo que atinge as pessoas que vivem em territórios que foram conquistados pelo El, além dos apoiadores do grupo. As próprias imagens presentes na matéria - conforme analisamos adiante - e a declaração a seguir comprovam isso: "Os anúncios encheram as ruas do Estado Islâmico com alegria fiel” (DABIQ, 2014, p. 7).

Também consta na matéria o valor-notícia de relevância e significatividade do acontecimento em relação aos desenvolvimentos futuros de uma determinada situação, já que essa notícia tem como desdobramento a espera pela conquista de mais territórios a partir do restabelecimento do Califado, por exemplo.

A matéria traz ainda o valor-notícia de brevidade, uma vez que o fato foi 
contado de maneira objetiva. Além disso, a ideia de novidade também está presente no texto, pois o acontecimento noticiado ocorreu em 29 de junho de 2014, seis dias antes de sua publicação.

Diferentemente desta, a matéria de capa da última edição abandona o recurso aos valores-notícia. Intitulada Quebrar a Cruz, ela tem como tema a exaltação ao islamismo e a crítica à crença cristã, como fica claro logo no primeiro parágrafo (DABIQ, 2016, p. 46, tradução nossa):

Ó Povo da Escritura, vamos chegar a um acordo, que só adoraremos a Alá, não fazendo parceiros para Ele, e que nenhum de nós irá adotar senhores além Dele. Se você se afastar, então você deve testemunhar que nos submetemos ao nosso Senhor (Al 'Imran 64).

A abertura do texto já evidencia a diferença com a matéria de capa da primeira edição tanto na temática como no recurso ao uso dos valores-notícia. Quebrar a Cruz não tem um formato jornalístico e não trata um acontecimento específico. Não há a rigor valores-notícia, pois, para que eles existam é necessário que haja um acontecimento. Há apenas um elemento que poderia se considerar como emulador de um dos valores-noticia estabelecidos por Wolf: grau e nível hierárquico das pessoas envolvidas, à medida que o texto cita alguns dos personagens centrais das religiões judaico-cristãs, como Adão, Noé, Abraão, José, Moisés e até mesmo Jesus Cristo.

\section{O SAGRADO E O PROFANO NO DISCURSO DO EI}

O islamismo foi fundado por Maomé (570-632) com o objetivo de mostrar uma ideia de submissão a Deus jamais expressa até então, com uma nova organização de Estado, a Umma e vivendo com as mensagens enviadas ao profeta que formaram o Alcorão. Em 610, segundo a tradição islâmica, Maomé foi visitado pelo anjo Gabriel, que o chamou de "mensageiro de Alá" e lhe comunicou o comportamento que se deveria ter e até o que se deveria vestir. Maomé, que pregava que as terras dos ricos deveriam ser dividas com os pobres, o que desagradava as classes dominantes em Meca, conseguiu muitos adeptos, mas também foi perseguido, o que o levou, em 622, a migrar para Medina. Ele retornaria a Meca em 624 para se tornar líder

1 Em árabe significa nação, comunidade. No islã, representa a comunidade muçulmana em todo o mundo. 
político e conduzir a união das tribos e clãs da sociedade árabe em torno da nova religião. Após sua morte, houve a consolidação o primeiro califa, seu sogro, Abu Bakr, que iniciou a luta pela conquista de terras exteriores já planejada por Maomé. Para Pereira (2017, p. 38-39):

Como a iniciativa encontrou fraca resistência e, de um modo geral, recebeu apoio das populações nativas, que sofriam sob a opressão dos Impérios Persa e Bizantino, o expediente transformou-se na bem sucedida empresa de expansão do Islã, que teve início, em 633, e continuou sob os três califas sucessores de Maomé: Abu Bakr: Omar, 634/644, Utman, 644-656 e Ali, 656/661. As conquistas foram surpreendentemente rápidas e constituíram a primeira fase do processo de construção do Império Islâmico.

O título de califa deixa de existir em 1924, com o fim do Império Ottomano. No entanto, em 2014, a figura do califa e a ideia maometana do califado são restaurados pelo Estado Islâmico, que autoproclama seu líder Abu Bakr al-Baghdadi como novo califa.

Nossa hipótese é que, ao resgatar o projeto político-religioso do califado, o Estado Islâmico está também reafirmando no campo político, militar e social a oposição entre profano e sagrado. Eliade (1992, p. 14) afirma que no mundo as coisas podem ser classificadas como sagradas, ao possuírem uma conexão com algo que transcende o mundo natural e é, portanto, não natural, ou profanas, ao serem consideradas totalmente naturais. O modo de ser profano prevalece quando as ações e coisas no mundo são consideradas como naturais. Por exemplo: o ato de se alimentar passou a ser considerado uma necessidade fisiológica e, portanto, profano, enquanto nas sociedades arcaicas a alimentação era considerada sagrada. Pode-se, assim, afirmar que o sagrado se define pela sua oposição ao profano. Já a história das religiões é composta por realidades sagradas. Relacionada à sacralidade, Eliade propõe a ideia de hierofania, que consiste em uma manifestação reveladora do sagrado. Para Eliade (1992, p. 13):

A partir da mais elementar hierofania - por exemplo, a manifestação do sagrado num objeto qualquer, urna pedra ou uma árvore - e até a hierofania suprema, que é, para um cristão, a encarnação de Deus em Jesus Cristo, não existe solução de continuidade.

Assim como Jesus é considerado sagrado no cristianismo, o profeta Maomé o é no islamismo. Porém, ao comparar o aspecto de continuidade no 
que é considerado sagrado no cristianismo e no islã, é possível notar que, enquanto Jesus Cristo é visto como único, sem um sucessor, no islã, Maomé possui sucessores: os califas. Em ambos os casos é possível encontrar a manifestação ou revelação de algo, como classifica Eliade, "de ordem diferente", mas que ainda assim está presente no mundo profano, pois tanto Jesus no cristianismo como Maomé no islamismo são vistos como homens que viveram suas vidas normalmente, mas que foram enviados por Deus para manifestarem a vontade dele na Terra, o que causa um certo atrito entre essas duas crenças. O que é considerado sagrado varia de acordo com a religião. Algo considerado sagrado no cristianismo pode não ser visto como tal no islã e vice-versa.

Na revista Dabiq é possível observar a oposição sagrado e profano. Um exemplo disso é a referência a Maomé como sagrado, chamado de mensageiro de Alá, e a Jesus Cristo como profano e o uso do argumento de que o Novo Testamento não é um relato verdadeiro enquanto o Alcorão é o livro correto a seguir, remetendo ao que citou Eliade (1992, p. 14): "a oposição sagrado/profano traduz-se muitas vezes como uma oposição entre real e irreal ou pseudo real". Nesse sentido, Maomé é visto como uma realidade natural que está ligada a outra sobrenatural: "manifestando o sagrado, um objeto qualquer torna-se outra coisa e, contudo, continua a ser ele mesmo, porque continua a participar do meio cósmico envolvente" (ELIADE, 1992, p. 13). Portanto, há um paradoxo, pois, ao mesmo tempo em que Maomé é considerado sagrado por ter sido o mensageiro de Alá, não pode ser visto como um Deus, mas sim como profeta. Além disso, essa contradição também ocorre no islã com a figura do califa como sucessor de Maomé.

Para estabelecer um discurso que diferencia o Estado Islâmico e seus ideais como sagrados, o grupo recorre a textos e imagens persuasivos dessa ideia. Pois, ainda que a matéria da primeira edição de Dabiq possua todos os valores-notícia, ela não está isenta de persuasão. Como afirma Citelli (2004, p. 6): "é possível afirmar que o elemento persuasivo está colado ao discurso como a pele ao corpo", e o que acontece é que existem diferentes graus de persuasão que podem ter maior ou menor visibilidade de acordo com o tipo de discurso, ou, como denomina Orlandi (1999, p. 84), tipologia.

Para Abreu (2011), a ideia de persuasão está relacionada com a de argumentação: argumentar se trata de convencer, mas, ao mesmo tempo também de persuadir, fazendo com que o outro realize o que queremos de maneira ética, sem exigências, mas deixando que ele faça suas escolhas com 
autonomia. O autor separa o convencimento da persuasão, relacionando o convencimento à razão e ao pensamento, enquanto relaciona a persuasão com a emoção e com o sentimento. Para Abreu (2011, p. 77), o homem não é um ser totalmente racional, mas é emocional, o que faz com que seja mais fácil persuadir do que convencer. Já não é novidade que o Estado Islâmico utiliza a persuasão por meio de vídeos divulgados apelando para os estados afetivos. Apesar disso, nas matérias publicadas na Dabiq, o grupo argumenta tanto pelo convencimento, como pela persuasão.

O discurso estabelecido pelo Estado Islâmico na Dabiq relacionado à oposição sagrado-profano recorre a uma figura de linguagem específica: a metáfora. Além disso, na matéria de capa da primeira edição da revista, para mostrar a proclamação do califado como algo bom, foram utilizadas outras figuras de linguagem, como a metonímia. Segundo Citelli (2004, p. 21), "pela metáfora cria-se um mecanismo de representação dos significados de um termo em outro termo". Ele ainda a divide em dois processos: o de transparência (ou transposição) e o de associação. O primeiro se caracteriza por passar da própria significação da palavra para o plano simbólico, enquanto o segundo está relacionado com o efeito figurativo.

É possível encontrá-la no trecho a seguir, que se trata de uma parte do discurso do novo califa (DABIQ, 2014, p, 7, tradução nossa):

Ó muçulmanos em todos os lugares, boas notícias para vocês e esperem o bem. Levantem a cabeça, pois hoje - pela graça de Alá - vocês têm um estado e um califa, que retornará a dignidade, o poder, os direitos e a liderança para vocês. É um estado onde os árabes e não-árabes, o homem branco e o negro, os orientais e os ocidentais são todos irmãos [...] O sangue deles misturou-se e tornou-se um, sob uma única bandeira e meta, em um pavilhão, gozando dessa bênção, a bênção da fraternidade fiel. Se os reis experimentassem essa bênção, eles abandonariam seus reinos e lutariam por essa graça. Então todos os elogios e agradecimentos são devidos a Alá.

Na parte em que o califa diz: "levantem a cabeça", se refere a uma metáfora muito comum que tem por objetivo fazer com que o leitor se anime com a novidade. Já em “o sangue deles misturou-se e se tornou um”, a ideia é a de que diversos povos, apesar de suas diferenças, se uniram com a proclamação do califado, assim, a ideia de que tal proclamação traz benefícios está presente. 
No mesmo trecho, também podemos notar a presença da metonímia, que, de acordo com Citelli (2004, p. 22), "indica a utilização de um termo em lugar de outro, desde que entre eles haja uma relação de contiguidade" e, segundo Abreu (2011, p. 115), "é o uso da parte pelo todo". Quando o califa diz "Alá uniu seus corações", a metonímia está presente, pois ele usa o órgão coração para dizer que Alá uniu esses homens pelo sentimento de alegria, uma vez que, por vezes o coração está relacionado com o sentimento. $\mathrm{O}$ fato de que as pessoas, de acordo com a matéria, ficaram felizes com o retorno do califado está ligado à ideia de sacralidade.

No discurso dado pelo califa, o subtítulo 0 mundo foi dividido em dois campos (DABIQ, 2014, p. 10 é por si só uma metáfora que faz menção a campos de batalha. O evento abordado divide o Estado Islâmico do resto do mundo - o Estado Islâmico sendo tratado como sagrado e todos os que se opõem à crença propagada pelo grupo como profanos. Além de mostrar que o Estado Islâmico está disposto a lutar contra outros tipos de crença para obter mais territórios (DABIQ, 2014, p. 10):

Ó nação do Islã, na verdade o mundo hoje foi dividido em dois campos e duas trincheiras, sem o terceiro acampamento presente: $\mathrm{O}$ acampamento do Islã e da fé, e o acampamento do kufr (descrença) e hipocrisia - o acampamento dos muçulmanos e mujahidin em todo lugar, e o acampamento dos judeus, os cruzados, seus aliados, e com eles o resto das nações e religiões de kufr, todas sendo lideradas pela América e pela Rússia, e sendo mobilizadas pelos judeus.

Independentemente do tipo de discurso, segundo Orlandi (1999, p. 80), ao compreendê-lo não apenas vemos o que está sendo escrito como também acabamos percebendo o que está implícito no discurso. Isso poderá ser visto, por exemplo, na primeira frase da matéria (DABIQ, 2014, p. 7, grifo nosso):

No primeiro de Ramadã $1435 \mathrm{H}$, a restauração do Califado foi anunciada pelo porta-voz do Estado Islâmico Shaykh Abu Muhammad al'Adnani ash-Shami (hafidhahullah).

A partir da ideia de restauração expressa no texto, mesmo que o leitor não tenha conhecimento sobre a história do islã e do califado, ele subentende que já existira um califa antes, que, por algum motivo, deixou de existir. 
Diferente da matéria de capa da primeira edição, em que todos os valores-notícia estavam presentes e que, de acordo com as teorias de Abreu (2011), classifica-se como um texto persuasivo, na matéria de capa da última edição de Dabiq, o Estado Islâmico busca convencer em vez de persuadir. Ela argumenta de forma incisiva que o Islã é a religião correta e não busca fazer com que o leitor crie um sentimento de identificação, como na matéria apresentada anteriormente.

O discurso de convencimento do grupo na matéria recorre à metáfora no título: Quebrando a Cruz, para representar que o texto irá desconstruir o que o leitor sabe sobre Jesus Cristo, pois a cruz é o que o representa. Assim, o Estado Islâmico se utiliza dessa figura de palavra para dizer que vai questionar tudo o que diz respeito sobretudo ao Novo Testamento. Mas, ao contrário da matéria $O$ retorno do Califa, nesta a metáfora não é muito utilizada, isso porque, de acordo com Citelli (2004, p. 20):

As figuras, ou translações, como as definem certos autores, cumprem a função de redefinir um determinado campo de informação, criando novos efeitos e que sejam de atrair a atenção do receptor. São expressões figurativas que conseguem quebrar a significação própria e esperada daquele campo de palavras.

Assim, a metáfora e outras figuras de linguagem não estão tão presentes nesta matéria porque são substituídas pelo uso constante de citações do Corão e da Bíblia, já que o grupo teve a intenção de mostrar o que seriam para ele as contradições na Bíblia Sagrada, citando o Corão como o livro que contém a verdade, como mostra este trecho do texto sob o subtítulo Trindade Pagã versus Unidade Monoteísta (DABIQ, 2016, p. 53, grifo nosso):

Quanto à evidência textual fornecida por seu clero, é ao mesmo tempo escassa e inadmissível. O conceito da Trindade é o aspecto mais importante da teologia cristã moderna. No entanto, embora seja de um significado tão extremo, não há texto direto na Bíblia. Ou seja, não há nenhum verso diretamente afirmando que "Deus é três. O Pai, o Filho e o Espírito Santo" Isto representava um grande problema para o clero trinitariano, cuja única solução foi inserir Tais alterações a um salário existente, enganando inúmeros adeptos em acreditar que a Trindade é apoiada pela Escritura. Na primeira das epístolas de João, pode-se encontrar: "Porque três são os que testificam no céu: o Pai, a Palavra, e o Espírito Santo; e três são um" (1 João 5: 7, KJV). [...] Quanto a falta de vergonha deles, aqueles que admitem isso, devem então considerar-se politeístas 
essenciais. [...] Isto não é diferente do uso muito comum, através do Corão monoteísta, do majestoso plural de Alá, que disse: "Nós não somos deus senão Eu, então, me adore "'(Qaf 43).

Apesar de haver diferenças entre a maneira como o discurso é propagado nas duas matérias, uma semelhança é que, em ambos, é possível, além de entender o que está sendo escrito, subentender o texto. Um exemplo disso em Quebrar a Cruz é (DABIQ, 2016, p. 62, tradução e grifo nosso):

\footnotetext{
Acredite em Alá, o Verdadeiro Rei, o Criador e o Único Deus, que não tem nem filho nem companheira, e que não foi gerado nem gerou. Adore o seu Senhor, que criou você e aqueles antes de você, para que você fosse justo. Ele fez para você a terra como uma cama, o céu como uma estrutura e enviou água do céu, produzindo frutos para o seu sustento. Portanto, não faça rivais com Alá enquanto você sabe.
}

O que é subentendido aqui é a ideia de que, se Alá é o verdadeiro Deus, então todos os outros são falsos, se ele é o criador, os outros não são o criador e, se ele é o único Deus, então os outros não são.

\section{A CONTRIBUIÇÃO DISCURSIVA DAS IMAGENS}

A relação entre o expresso e o não expresso no texto das matérias da revista também está presente nas imagens que elas trazem. Como afirma Barthes (1990), a imagem é composta não só pelo que vemos (linguagem denotativa), mas também pelo que não vemos, mas interpretamos (linguagem conotativa). Uma fotografia pode transmitir, ao mesmo tempo, dois tipos de mensagem: "Uma mensagem denotada, que é o próprio analogon e uma mensagem conotada que é a maneira pela qual a sociedade oferece à leitura, dentro de uma certa medida, o que ele pensa" (BARTHES, 1990, p. 13). Uma descrição de imagem seria inviável, uma vez que, ao olhar para ela sem notar sua conotação, não estaria a vendo por completo. "As fotos são signos que coalham, como leite. Seja o que for que ela dê a ver e qualquer que seja a maneira, uma foto é sempre invisível: não é ela que vemos" (BARTHES, 1984, p. 16). A conotação consiste na "imposição de um sentido segundo à mensagem fotográfica propriamente dita” (BARTHES, 1990, p. 15). As escolhas tomadas pelo emissor - visto que a fotografia é considerada pelo autor como uma mensagem - influenciam na maneira em que o receptor da fotografia irá recebê-la e artifícios, como a trucagem, a pose dos 
objetos, a fotogenia, o esteticismo e a sintaxe também fazem parte desse processo (BARTHES, 1990, p. 15).

As ideias de imagem conotativa e denotativa também estão presentes nas fotografias propagadas pelo Estado Islâmico. Pelo menos na primeira foto da matéria de capa (Figura 1) é possível perceber isso:

Figura 1: Capa da primeira edição da revista Dabiq

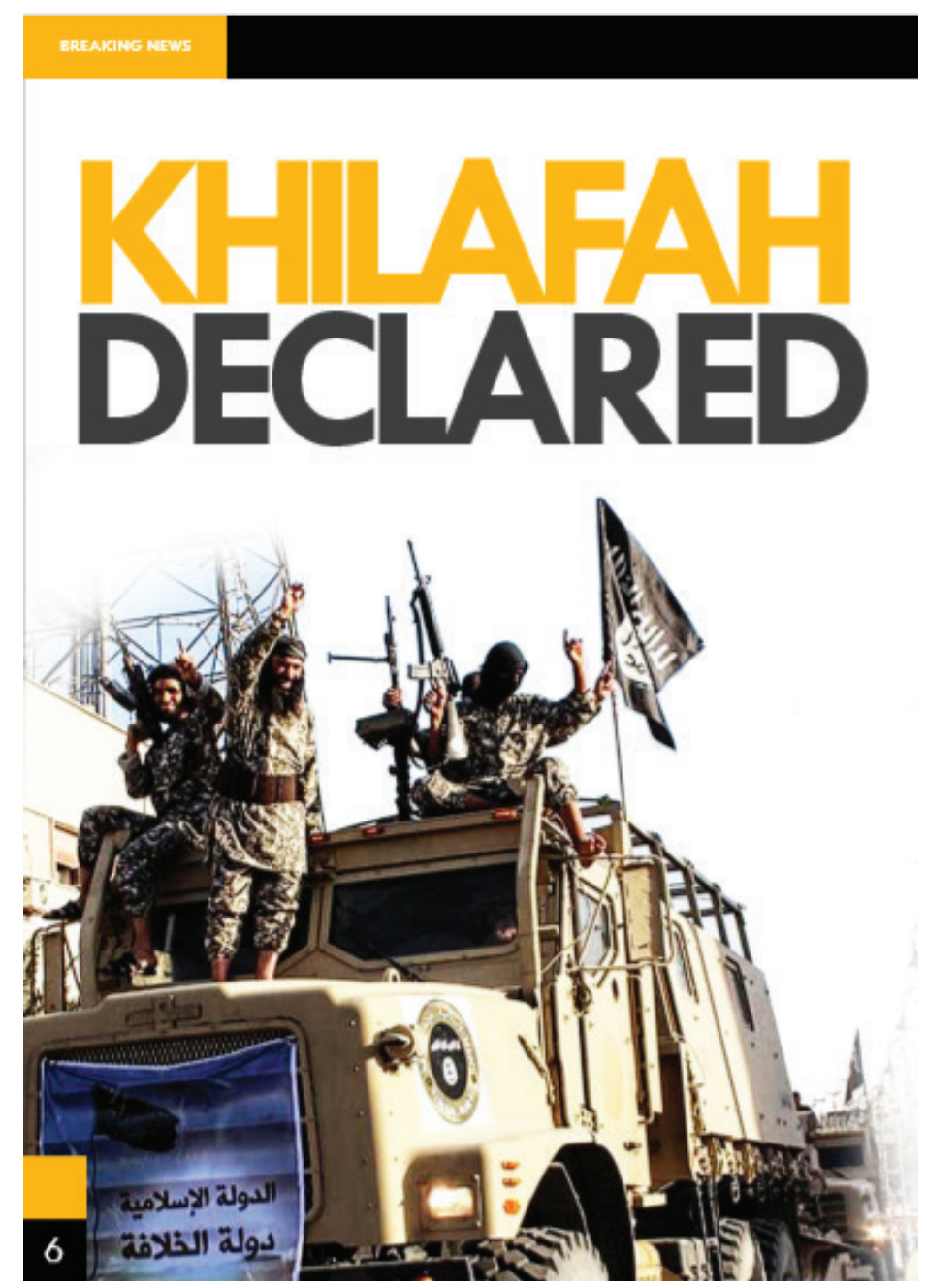

Fonte: Dabiq

Nessa imagem, o denotativo, ou seja, o que vemos são três homens segurando a bandeira do Estado Islâmico e armas enquanto estão em cima de um veículo de guerra, tudo isso sob uma imagem de fundo branca. No conotativo, ela enfatiza a ideia bélica, com a postura dos homens sobre o veículo aludindo à grandeza e disposição deles em lutar contra quem se opor ao El - reforçada pela presença da bandeira do grupo na imagem. O fundo branco pode remeter à ideia de luz, de iluminação divina. A própria bandeira do EI reforça a ideia de guerra santa, pois ela é conhecida como bandeira negra e 
atualmente tem por significado principalmente $\mathrm{o}$ jihadismo ${ }^{2}$. $\mathrm{O}$ texto escrito com letras brancas sobre o fundo preto (Figura 2) significa: "Não há outro Deus além de Alá", dentro do círculo branco - que seria o selo de Maomé estão as palavras "Alá”, "Rasul” (Profeta) e "Maomé”.

Figura 2: Bandeira do Estado Islâmico

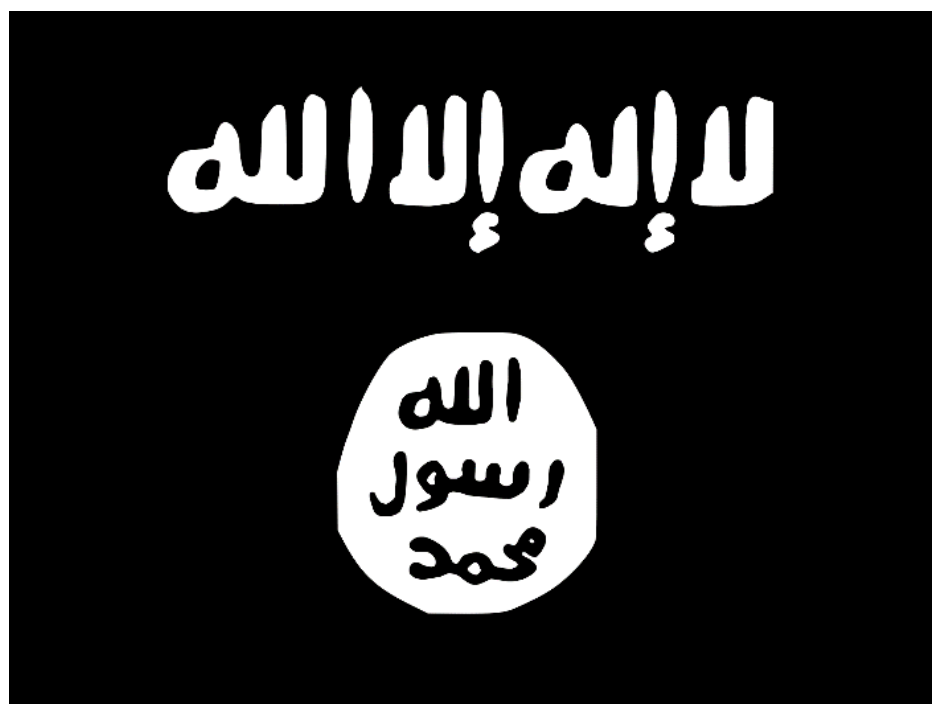

Fonte: Dabiq

A relação entre imagem e texto já foi discutida inúmeras vezes por diversos autores, como citam Santaella e Noth (1997, p. 54). A abordagem feita por Kalverscamper diferencia três tipos de relações que podem ocorrer entre imagem e texto: redundância (que se trata da ideia de que a imagem é inferior ao texto e o complementa), informatividade (se refere a ideia de que a imagem é superior ao texto, sendo mais informativa do que ele) e complementaridade (quando ambos têm a mesma importância). Na matéria de capa da primeira edição, é possível notar uma relação de complementaridade, já que, em sua primeira imagem, a ideia de guerra se relaciona com a de sagrado e profano, expressa no próprio texto. Comprovando também o que citou Barthes (1984, p.15):

A Fotografia pertence a essa classe de objetos folhados cujas foIhas não podem ser separadas sem destruí-los: a vidraça e a paisagem, e por que não: o Bem e o Mal, o desejo e seu objeto: dualida-

2 É considerado um dos pilares da fé islâmica. O termo jihad é tradicionalmente utilizado para descrever o dever dos muçulmanos de disseminar a fé muçulmana. Tem por traduções: "luta”, "esforço" ou empenho, mas por vezes também é traduzido como "guerra santa". 
des que podemos conceber, mas não perceber [...].

Além disso, imagens de pessoas felizes são sempre mostradas, enquanto o texto cita a alegria das pessoas para com a notícia, além dos discursos do porta-voz do grupo e do novo califa do Estado Islâmico citarem o califado como um benefício. Já no início da matéria isso é enfatizado, com algumas imagens (Figura 3):

Figura 3: Parte da página 7 da primeira edição da revista

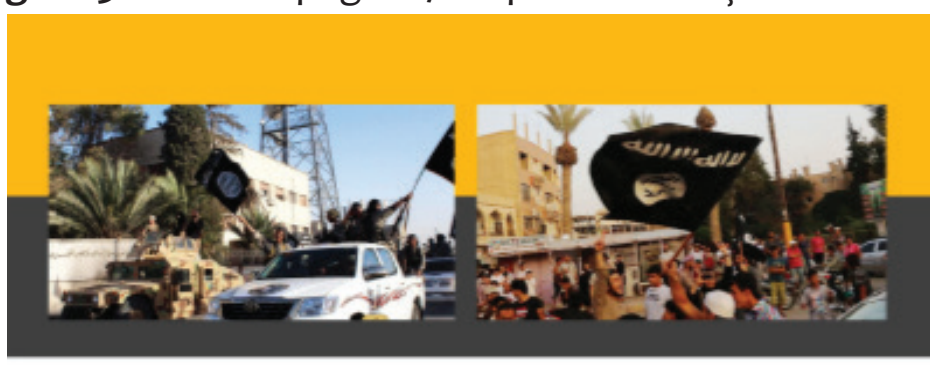

On the first of Ramadan $1435 \mathrm{H}$, the The announcements filled the streets of the revival of the Khilafah was announced by the spokesman for the Islamic State, Shaykh Abu Muhammad al'Adnani ash-Shami (hafidhahullah). Islamic State with faithful joy.

May Allah continue to fill the hearts of the Muslim Ummah with news of victong, thereby guiding them towards obedience of His The good news was followed by the first official Messenger Muhammad (sallallahu 'alayhi wa speech of Amirul-Múm minin Abu Bakr al-Husayni al-Qurashi at-Baghdadi (nasarahullah).

Below are some of the most importont excerpts from the two speeches.

Fonte: Dabiq

O terceiro parágrafo cita a alegria das pessoas após esse anúncio, cita também que elas cobriram as ruas com alegria, enquanto, acima do texto, a imagem materializa esse discurso visualmente. Parte do discurso do então porta-voz do El seguido de três imagens na nona página da revista (Figura 4) também comprova a existência da complementaridade entre imagem e texto na matéria analisada:

Chegou a hora para aquelas gerações que estavam se afogando em oceanos de desgraça, sendo amamentadas no leite da humilhação e sendo governadas pelo mais vil de todas as pessoas, depois de seu longo sono na escuridão da negligência - chegou a hora deles subirem (DABIQ, 2014, p. 9, tradução nossa). 
Figura 4: Página 9 da primeira edição da revista Dabiq

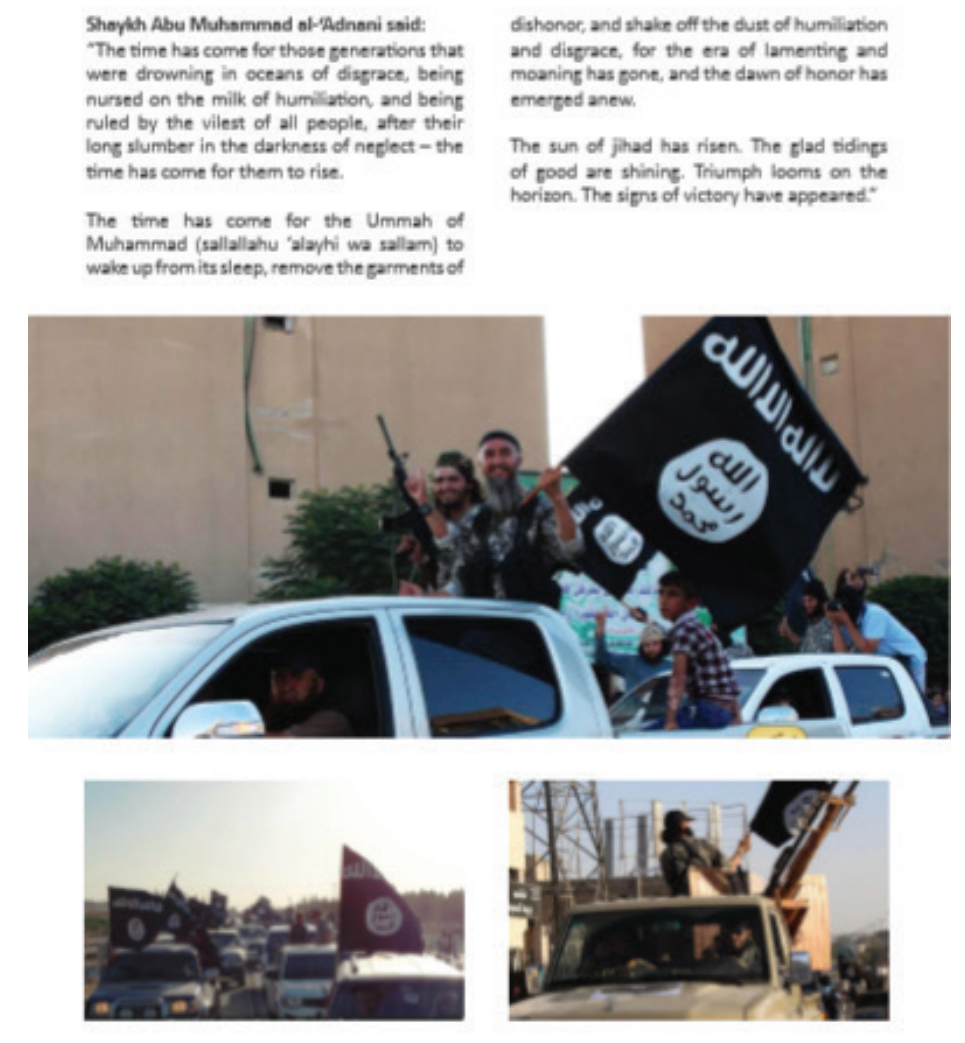

Fonte: Dabiq

Nenhuma das nove imagens da matéria contém legenda, sendo que a contextualização das fotos está no próprio texto. Outro fato interessante é que, em todas as imagens, a bandeira do Estado Islâmico está presente.

Na matéria de capa da última edição da Dabiq, imagem (Figura 5), é possível ver três homens empurrando uma cruz, para derrubá-la. Um deles está segurando uma bandeira do El. O que não está exposto na imagem, mas é possível notar por meio da conotação, é que a intenção do grupo de derrubá-la remete a derrubar os pensamentos cristãos, já que, como foi dito anteriormente, a cruz é o que representa Jesus Cristo. 
Figura 5: Capa da última edição de Dabiq

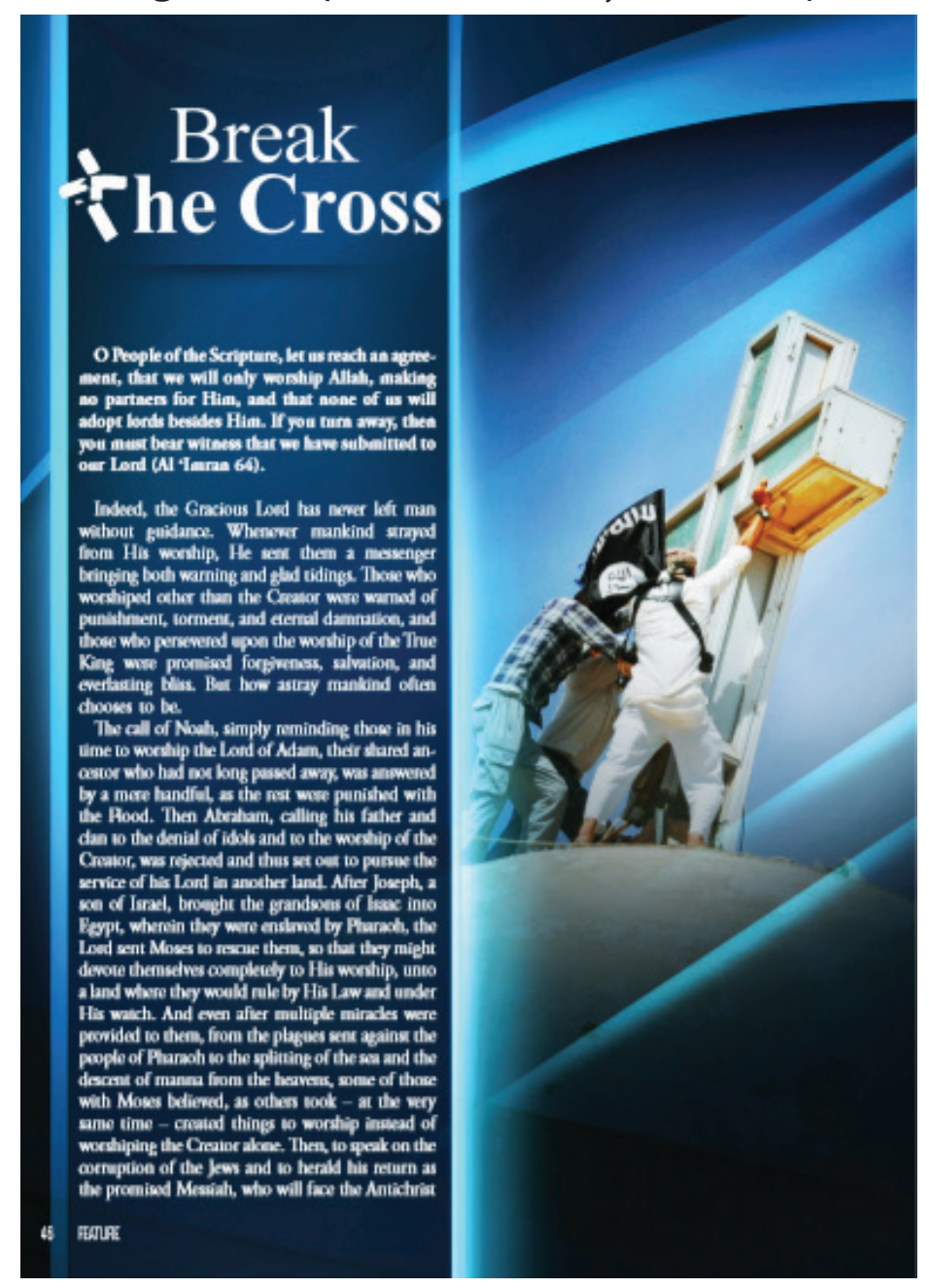

Fonte: Dabiq

Para enfatizar essa ideia da quebra da cruz e, então dos ideais do cristianismo, também foi usada uma letra em forma de cruz quebrada no título da matéria (Figura 6):

Figura 6: Capa da última edição de Dabiq

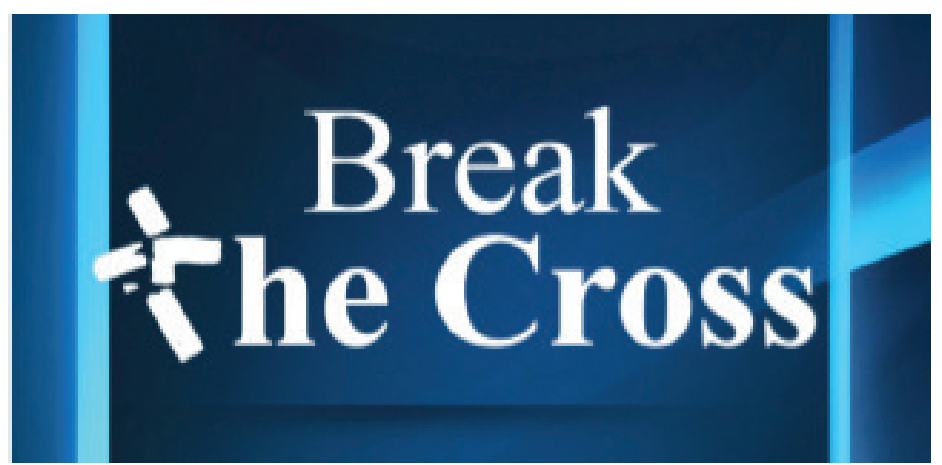

Fonte: Dabiq

Na matéria em questão, é possível notar uma relação de complementari- 
dade, já que, em sua primeira imagem, a ideia de quebra da cruz se relaciona com a de sagrado e profano, expressa no próprio texto. Além disso, enquanto uma parte do texto diz:

No entanto, assim como a Torá3 não foi totalmente preservada, e foi inclusive alterada, o Evangelho também foi corrompido. Seu original seria perdido, com os mais antigos manuscritos relacionado escritos apenas como comentários ao original. [...] Para dizer o mínimo, a escritura autêntica foi perdida e as pessoas se desviaram (DABIQ, 2016, p. 47, tradução nossa).

A imagem na mesma página (Figura 7) mostra um homem escrevendo, assim a imagem conotativa é a de que ele representa alguém alterando a Torá ou a Bíblia, dando a entender que ela poderia ter sido escrita por qualquer pessoa, complementando assim o texto.

Figura 7: Imagem presente na página 47 da revista Dabiq

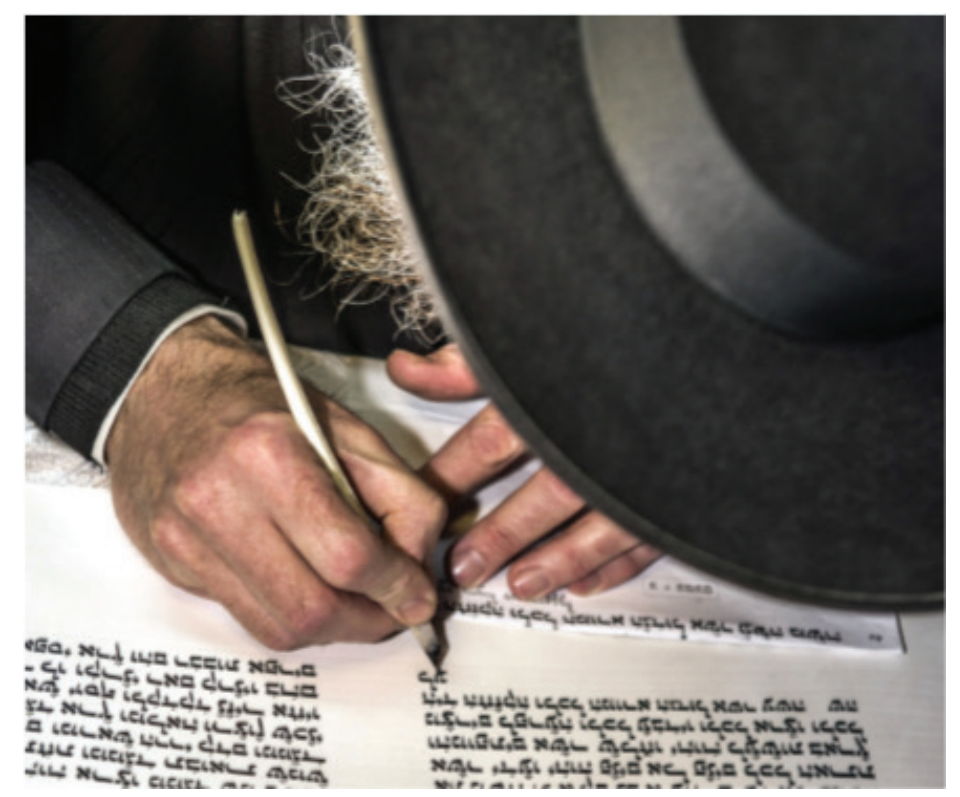

Fonte: Dabiq

Assim como na matéria analisada anteriormente, aqui as ideias de sagrado e profano também estão presentes em imagem e texto. Como na imagem da página 62 (Figura 8), que tem como legenda "aliados de Alá indo para a batalha", sob a imagem de homens em cima de um carro. Além disso,

3 Palavra oriunda do hebraico que tem por significado "instrução", "ensinamento" ou "apontamento". São os cinco livros que constituem a base do judaísmo: Gênesis, Êxodo, Levítico, Números e Deuteronômio. 
mais uma vez a bandeira do El aparece na imagem.

Figura 8: Islâmicos indo para a batalha

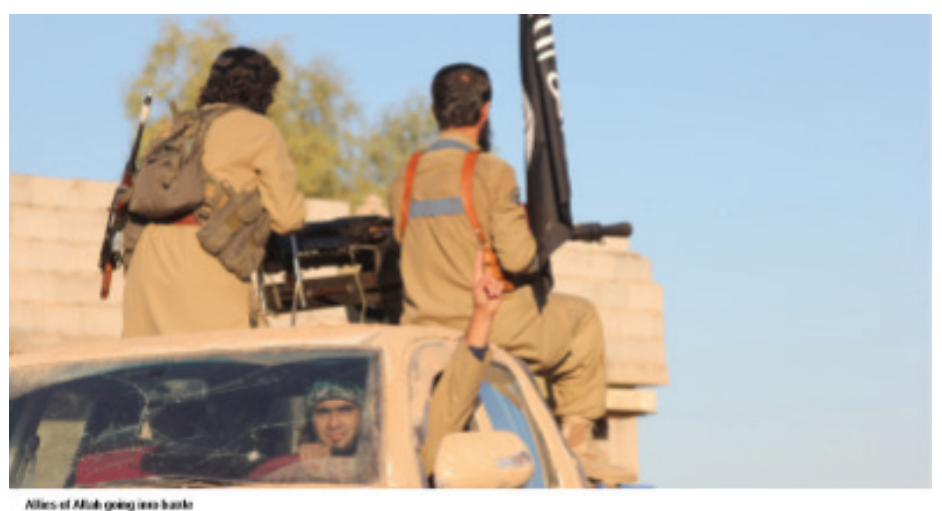

Fonte: Dabiq

\section{CONCLUSÃO}

Uma das constatações desta investigação diz respeito aos valores-notícia nas matérias principais da revista Dabiq. Enquanto na primeira edição esses valores estão presentes, na última eles estão totalmente ausentes. Se considerarmos que o primeiro número da Dabiq é lançado em um momento favorável ao El, quando ele expandia seus domínios com novos territórios conquistados, e o último quando a organização encontrava-se em decadência e sofrendo inúmeras derrotas, pode-se estabelecer um paralelo entre uma busca de legitimação nos momentos positivos a partir da valorização de um discurso fundado em elementos racionais e nos momentos negativos o abandono desses valores e a construção de um discurso explicitamente emocional, ainda que em ambos a oposição do sagrado e do profano esteja no centro discursivo.

Em contrapartida, apesar da discrepância com relação aos valores-notícia em seu período de declínio, o grupo utiliza - inclusive com mais intrepidez - a oposição sagrado-profano, pois o faz para tratar outras crenças como falsas. Para isso, de maneira contraditória, o Estado Islâmico se utiliza de mídias - que são algo profano - como a internet, para não apenas propagar suas ideias de sagrado, mas também conseguir adeptos a elas. Para tal, utiliza, ao contrário da primeira matéria, estratégias de convencimento, deixando de usar o sentimento do leitor para conquistá-lo e tentando desconstruir suas ideias. 
A partir disso, também é possível concluir que, seja para persuadir ou convencer,

os sentidos conotativo e denotativo são vistos nos textos e imagens das duas matérias. Para estabelecer esse tipo de discurso em seus textos, o grupo se utiliza das figuras de linguagem - sobretudo a metáfora e a metonímia - para afirmar sua posição como objeto sagrado. Elas são frequentemente empregadas na matéria de capa da primeira edição e não tão usadas na última publicação.

Ademais, apesar do fato de que o Estado Islâmico pertence a uma vertente mais extremista do islã, na revista, o grupo estabelece um discurso que tem como objetivo reviver a ideia maometana de união dos árabes, a partir da aproximação entre religião e política. Dabiq propaga esse discurso, em sua primeira edição, com a ideia de sacralidade do califa, que, apesar de não ser considerado um ser superior, é visto como sagrado, ou escolhido por Alá. Foi possível identificar que o grupo une, na primeira e na última matéria de capa da revista Dabiq, as ideias de sagrado e profano, sentidos conotativos e denotativos em imagens e textos, valores-notícia e estratégias de persuasão/convencimento, de forma pragmática, de acordo com seus interesses e objetivos políticos e sua posição em relação ao poder.

Assim, vimos que, sob a suposta legitimidade do discurso jornalístico - que a princípio associa aos textos características de objetividade e imparcialidade na representação da realidade -, a revista Dabiq constrói um discurso político que opera justamente com características opostas, fundadas na subjetividade e na parcialidade oriundas da defesa dos valores da fé islâmica. Um dos principais recursos nesse sentido é o uso da oposição sagrado-profano de forma patente ou latente em seus textos e imagens. Uso que se apresenta de forma mais sutil em situações favoráveis ao Estado Islâmico e de forma mais evidente em situações desfavoráveis.

Esta investigação pode a partir de uma análise inicial desse tipo de publicação apontar as contradições entre um pretenso discurso jornalístico contemporâneo e profissional - fundado em valores iluministas - e o discurso político-religioso efetuado na prática pela revista. Esperamos que esta análise possa ser um ponto de partida para novas pesquisas sobre o tema abrangendo um corpus mais amplo.

\section{REFERÊNCIAS}

ABREU, Antônio S. A arte de argumentar: Gerenciando Razão e Emoção. 13. ed. Cotia: 
Ateliê, 2011.

BARTHES, Roland. A câmara clara. Rio de Janeiro: Nova Fronteira, 1984.

BARTHES, Roland. O óbvio e o obtuso. Rio de Janeiro: Nova Fronteira, 1990.

CITELLI, Adilson. Linguagem e persuasão. 16. ed. São Paulo: Ática, 2004.

ELIADE, Mircea. O sagrado e o profano. São Paulo: Martins Fontes, 1992.

FOX NEWS. Pentagon confirms it killed senior ISIS leader Abu Muhammad al-Adnani. Disponível em: <http://www.foxnews.com/world/2016/09/12/pentagon-confirms-it-killed-senior-isis-leader-abu-muhammad-al-adnani.html>. Acesso em: 11 set. 2018.

GAMBHIR, Harleen. The Virtual Caliphate: ISIS's Information Warfare. Washington, DC: Institute for the Study of War, 2016.

ORLANDI, Eni Puccinelli. Análise de discursos: princípios \& procedimentos. Campinas: Pontes, 1999.

PEREIRA, Antônio Celso Alves. O Estado Islâmico e o restabelecimento do Califado. Revista Interdisciplinar de Direito, [S.I.], v.12, n.1, p.31-46, out. 2017. Disponível em: <http:// revistas.faa.edu.br/index.php/FDV/article/view/111>. Acesso em: 12 set. 2018.

SANTAELLA, Lucia; NOTH, Winfried. Imagem, cognição, semiótica e mídia. Editora lluminuras: São Paulo, 2001.

WOLF, Mauro. Teorias das comunicações de massa. São Paulo: Martins Fontes, 2008. 


\section{Gabriela Cristina da Silva}

Bacharel em Jornalismo pelo FIAM FAAM Centro Universitário.

E-mail: gabicristina97@hotmail.com

\section{Sílvio Antonio Luiz Anaz}

Doutor em Comunicação e Semiótica pela PUC-SP. Pós-doutorado em Meios e Processos Audiovisuais pela ECA/USP.

E-mail: silvioanaz@hotmail.com 